\title{
ECONOMIC ANALYSIS OF THE FACTORS INFLUENCING THE SUPPLY AND DEMAND OF RASPBERRY
}

\author{
Nemanja Pantić ${ }^{1}$, Drago Cvijanović ${ }^{2}$, Nedžad Imamović ${ }^{3}$ \\ *Corresponding author E-mail: nemanja.pantic@kg.ac.rs
}

A R T I C L E I N F O
Original Article
Received: 14 September 2021
Accepted: 11 November 2021
doi:10.5937/ekoPolj2104077P
UDC
[338.439.4:338.33]:634.711

Keywords:

supply, demand, balance

analysis, correlation

dependence, raspberry

JEL: G00, H40, F10

\begin{abstract}
A B S T R A C T
The subject of this research is the analysis of supply and demand of raspberries on the domestic market in order to performe a balance analysis of products and examine the partial influence of relevant factors on supply and demand. The production and consumption of raspberries in Serbia in the period from 2010-2019 is very dynamic. Raspberry production in the Republic of Serbia has significant comparative advantages compared to production in most other countries. Serbia is considered one of the largest producers of raspberries, but still, regardless of that, its comparative advantages have not been fully valorized and used. The results of the balance analysis of raspberry production and consumption indicate the existence of a surplus and potential for export. The analysis of ANOVA variances established a high correlation dependence and pointed out the need to improve competitiveness in the production of raspberries and final products in order to meet the domestic market and exports to the world market. The obtained results enabled the formulation of regression equations of both the function of raspberry supply and its demand, which can be used to predict these values in the future.
\end{abstract}

(C) 2021 EA. All rights reserved.

\section{Introduction}

Supply and demand are the two most commonly used terms and represents the forces that enable the functioning of market economies. They determine the quantity and price of each produced good. (Mankiw, 2008; Mankiw \& Taylor, 2008). In the effort to more

1 Nemanja Pantić, Ph.D., Assistant Professor, University of Kragujevac, Faculty of Hotel Management and Tourism in Vrnjačka Banja, Vojvođanska 5A, 36210 Vrnjačka Banja, Serbia. Phone: +381 612058 758. E-mail: nemanja.pantic@kg.ac.rs. ORCID ID (https:// orcid.org/0000- 0003-0030-6950)

2 Drago Cvijanović, Ph.D., Full Professor, University of Kragujevac, Faculty of Hotel Management and Tourism in Vrnjačka Banja, Vojvođanska 5A, 36210 Vrnjačka Banja, Serbia. Phone: +381 63295 111. E-mail: dvcmmv@gmail.com. ORCID ID (https://orcid. org/0000-0002-4037-327X)

3 Nedžad Imamović, Ph.D., Assistant Professor, Ministry of Defense, Gardijska 7, 11000 Belgrade, Serbia. Phone: +38163 8755 673. E-mail: nedzimam66@gmail.com. ORCID ID (https://orcid.org/0000-0002-8067-056X) 
precisely define the concept of supply, it is important to emphasize that supply is the final stage of the production process in the market economy (Stanković, 2020; Jokić, 2020). The quantity of goods or services offered by producers on the market depends on the price of that good or service, the price of other goods or services, the income of consumers and other factors (Babić, 2004). Thus, the supply represents the quantity of goods or services produced by the entrepreneur, in order to be sold on the market, at the price formed in accordance with the specific conditions of the functioning of the market mechanism (Đorđević, 2006). According to the law of supply on the market, there is a direct positive correlation between price and supply. The total sum of individual offers of producers on the market represents the global or aggregate offer of a product on the market, the sum of offers of individual companies at a certain price (Babić, 2004).

In market theory, ie in the study of market laws, the central place is occupied by the analysis of market demand (Porter, 1990). Demand is considered to be the main driver of economic activity, reproductive and investment consumption. Production activities are accompanied by consumption, which is defined as the quantity of goods that can be sold at any price in a certain market at a certain time (Babić, 2004). The movement of individual demand is largely conditioned by the price level. That is why is said that demand in the narrower sense of the word is a function of the price of that good (Babić, 2004).

Speaking of markets and making individual and total profits, it is important to point out the existence of many factors, both economic and non-economic. The most important factor which affects on the realization of profit is certainly the structure, ie the characteristics of the market. Numerous factors can affect the market position of the any company (Đorđević, 2008). Samuelson emphasized the great importance that in the mass of products, for a successful market competition, it is crucial that the product must be different, even in one segment from others (Đordjevic, 2008).

Analyzing the market organization of the agricultural products in Serbia, there would be no encouraging data (Šapić et al, 2018; Filipović \& Šapić, 2020; Đorđević \& Mitić, 2020). Namely, it is much more disorganized than, not only in Europe, but also in the surrounding countries. The raspberry market in Serbia has the characteristics of a perfectly competitive market on the supply side and the characteristics of ologopol on the demand side. In the raspberry market, there is a disorganization of purchases, producers and processors.

In order to valorize the comparative advantages in the production of raspberries, which Serbia has at its disposal, a more active role of the state is needed (Pejanović, 2007). First of all, the state should stimulate producers to expand their plantations as well as the production of processed products with purchase prices (Božidarević, 2002; Hanić, 1990; Hanić, 2005). This is exactly the type of product whose sale on the global market can make an additional profit for the benefit of the entire economy. Manufacturers must not be left in the belief that they are left to fend for themselves, which is indeed sometimes the case (Samuelson, 2007; Jurin \& Šohinger, 1990). The dissatisfied producer is then constantly questioning whether to continue production. In many cases, 
the production of raspberries in Serbia is a family and traditional business that is passed from one generation to another, which would make the damage from the cessation of this activity many times greater (Bodiroga \& Sredojević, 2017; Temelkov, 2020). This is not what any society wants, sending very bad message to the future generations who are full of enthusiasm but also experientially acquired knowledges.

\section{Literature review}

Wróblewska et al. (2019) dealt with the analysis of raspberry production and comparative analysis on the example of Serbia, Poland and Ukraine. The results showed that Ukraine is a growing power in raspberry production. The offer has multiplied in recent years, which has strengthened Ukraine's export potential and thus its positioning on the world market. The results of exceptional price competitiveness of production in Ukraine are in extremely low production costs, which leaves room for producers to calculate their prices without neglecting to make a profit on the one hand, but also a competitive price that gives an advantage on the global market.

Radosavljević (2016) dealt with the problem of raspberry production in small production farms and the efficiency of using resources in order to make production, and thus the price, competitive on the market. Also, she came to the conclusion that Serbia did not use its comparative advantages in raspberry production due to inadequate financing policy due to which there was no significant growth of the field under raspberries. This is one of the reasons for insufficient price competitiveness and inadequate supply as it can be, having in mind the comparative advantages that Serbia has at its disposal.

Paraušić \& Simeunović (2016) dealt with the issue of weaknesses and strengths of raspberry producers in Serbia. Among other things, they pointed out that Serbian raspberry producers have one of the leading positions on the global raspberry market. In order to maintain that position, it is necessary for raspberry producers to achieve better communication, which can only help in the unified position of all producers, ie the offer of raspberries in Serbia. They emphasized the growing importance of marketing activities, which is one of the most important elements of successful market positioning in modern business.

Bojkovska et al (2020) dealt with the analysis of raspberry production in Northern Macedonia as well as the possibilities of its improvement. In addition, they also analyzed the global raspberry market, and stated that Russia is the leader in its production, while Mexico and the Republic of Serbia are slightly behind. These three countries produce almost $50 \%$ of the total world production of raspberries. The growth of world production is never higher because each year is a double-digit percentage growth. They believe that Northern Macedonia should follow the examples of good practice of the surrounding countries and use its potentials, which certainly has. Also, the demand for raspberries in Northern Macedonia is much higher than its supply, which results in extremely high prices that are not competitive on the global market what makes export almost impossible. They said that the export of raw raspberries is not a chance that Northern Macedonia has, but all 
potentials must be focused on the export of processed raspberries and products that can be offered on the world market. Thus, they emphasized the importance of the multiplied income that will come to the country through exports.

Farnsworth et al. (2017) performed analysis and market position of organic raspberry producers. The fact is that organic products are more expensive and more difficult to access for the average customer than those that cannot be considered organic. Nevertheless, the unsaturation of the market with organic products gives room for better positioning and making higher profits. As a rule, the demand for organic products is lower, but once customers decide to buy these products, they stay for a long period of time. That is why the demand for these products is more constant and customers are more loyal and long-term. For these reasons, it is important to position supply in markets where demand bearers are richer, ie in developed markets.

Apáti (2014) analyzed the position and perspective of raspberry producers in Hungary. The results he obtained indicates drastic decline in its production. He notes that there has been a multiple decline in the area of raspberry plantations, which he considers a consequence of inadequate cost policy. The costs of raspberry production in Hungary are extremely high, which does not allow for adequate market positioning and its sale even on the domestic market. The reason is the extremely price-competitive raspberry from imports, primarily from Serbia, which is also of much better quality. It also points to an insufficiently trained and interested workforce. He also believes that the state must accelerate the production of raspberries with its measures in order for the offer to be adequate and competitive not only on the domestic but also on the foreign market.

Milić et al. (2017) analyzed the production of raspberries in Serbia, but also its export to the global market. They noticed that the producers are increasingly oriented towards the modern way of production as much as they can in their financial power. Exports are growing and the share of total production, which is intended for the domestic market, is decreasing, and a lack is often noticed and the need for even higher production is shown. Also, raspberry growers are increasingly noticing the importance of marketing activities that are considered a necessity rather than a choice in the modern business environment. If we look at the demand side, it is noticeable that customers are increasingly oriented to well-known brands that, in addition to quality, are built with adequate and constantly present marketing activities. For that reason, the realization of the profit of a modern producer is conditioned by the increasing expenses that are necessary to invest in the entire production process. Smaller producers may initially have difficulties for this reason due to the lack of initial capital.

\section{Materials and methods}

The subject of the research is the analysis of supply and demand of raspberries on the domestic market, with the aim of performing a balance analysis of products and examining the partial influence of relevant factors on supply and demand. The paper analyzes the production and consumption of raspberries in Serbia in the period 2010- 
2019. A balance sheet analysis was performed based on time periods lasting three years. Correlation analysis was used to obtain the desired results and set goals. The offer of raspberries was considered, ie the effect of prices, consumption and imports on it. In addition, the demand for raspberries was also considered, ie how price, GDP and exports affect it.

The qualitative - quantitative research method is applied in the paper. For the purposes of the analysis, data in the period 2010-2019 from Statistical Office of the Republic of Serbia but also many other sources which will be listed below.

The influence of relevant factors on the supply and demand for raspberries was considered by multiple linear correlation analysis. The multiple linear equation can be represented as (Kiš, 2005):

$\mathrm{Y}=\mathrm{a}+\mathrm{b}_{1} \mathrm{x}_{1}+\mathrm{b}_{2} \mathrm{x}_{2}+\mathrm{b}_{3} \mathrm{x}_{3}+\ldots \ldots+\mathrm{b}_{\mathrm{n}} \mathrm{x}_{\mathrm{n}}, \mathrm{R}, \mathrm{Sy}, \mathrm{r}_{1}, \mathrm{r}_{2} \ldots . . \mathrm{r}_{\mathrm{n}}$,

The presence of correlation and its probability was confirmed by analysis of variance (ANOVA). Also were exmined the influence and significance of each coefficient by T-test. The value of the partial correlation was also determined.

\section{Results}

The paper discusses the production and consumption of raspberries. In order to achieve the set goals and expected results, were used available datas, which were grouped into time frames lasting 3 years, which were then the subject of correlation analysis. In our conditions, the production and supply of agri-food products (which includes raspberries) are relatively unstable economic and market categories. Consumption has a low coefficient of elasticity, which is why the demand, ie market consumption of these products is a relatively stable market category (Đorović \& Tomin, 2010).

The balance analysis examined the realistically available production and consumption and determined the balance surplus or deficit of raspberries. Based on the surplus and deficit, conclusions were clearly drawn about the possibility of its export.

In the examination of the influence of individual factors, were considered all relevant factors which affects on production and consumption of raspberries In that manner, the comprehensive balance sheet analysis responded to the goal of the paper, to look at the available balance quantities for exports and the factors that affect production and available consumption. At the same time, based on the balance of production, consumption and foreign trade of raspberries, the impact of certain categories on supply and demand was analytically measured. (Babović, 2009).

The total available production of raspberries in the ten-year period is the production in the amount of 98.54 thousand tons. Total consumption of raspberries on the domestic market in the period 2010-2019 is an average of 23.92 thousand tons. The balance difference between the total available production and consumption is the available quantities for export in the amount of 74.62 thousand tons. 
Raspberry is a Serbian brand. The raspberry fruit is of high quality and there is a permanent demand for it on the foreign market. Therefore, it is necessary to invest in raising raspberry plantations and programmatically organize the production and export of raspberries. Raspberry production in 2019 is on larger areas compared to the previous year, so export is expected to increase.

Table 1. Balance of production and consumption of raspberries in Serbia in thousands of tons

\begin{tabular}{|c|c|c|c|c|c|c|c|c|}
\hline Category & $\mathbf{2 0 1 0}$ & $\mathbf{\varnothing 1 0 - 1 2}$ & $\mathbf{\varnothing 1 3 - 1 5}$ & $\mathbf{\varnothing 1 6 - 1 8}$ & $\mathbf{2 0 1 9 .}$ & $\begin{array}{c}\text { index } \\
\mathbf{1 3 - 1 5 / 1 0 - 1 2}\end{array}$ & $\begin{array}{c}\text { index } \\
\mathbf{1 6 - 1 8 / 1 3 - 1 5}\end{array}$ & $\begin{array}{c}\text { index } \\
\mathbf{1 9 / 1 0}\end{array}$ \\
\hline Initial stocks & 0 & 5,5 & 1,69 & 0 & 0 & 30,73 & - & - \\
\hline $\begin{array}{c}\text { domestic } \\
\text { production }\end{array}$ & 61,6 & 92,4 & 110,89 & 104,23 & 113,1 & 120,01 & 93,99 & 183,60 \\
\hline $\begin{array}{c}\text { Total } \\
\text { quantities } \\
\text { available }\end{array}$ & $\mathbf{6 1 , 6}$ & $\mathbf{9 7 , 9}$ & $\mathbf{1 1 2 , 5 8}$ & $\mathbf{1 0 4 , 2 3}$ & $\mathbf{1 1 3 , 1}$ & $\mathbf{1 5 0 , 7 3}$ & $\mathbf{9 3 , 9 9}$ & $\mathbf{1 8 3 , 6}$ \\
\hline Final stocks & 0 & 1,1 & 1,69 & 0 & 0 & 10,22 & - & - \\
\hline $\begin{array}{c}\text { Total domestic } \\
\text { consumption }\end{array}$ & 21,89 & 17,6 & 17,29 & 23,16 & 26 & 98,24 & 133,95 & 118,78 \\
\hline $\begin{array}{c}\text { Total } \\
\text { consumption }\end{array}$ & 21,89 & 18,7 & 18,98 & 23,16 & 26 & 108,4586 & 133,95 & 118,78 \\
\hline surplus & 39,71 & 79,2 & 93,6 & 81,07 & 87,1 & & & \\
\hline
\end{tabular}

Source: RZS and author's calculation

The balance analysis shows that the total available raspberry production in 2019 compared to 2010 increased by $87.1 \%$. In the ten-year period, the yield was increased, and considering the larger areas under raspberries, the supply and the possibility of export were also increased. Total consumption in 2019 increased by $18.78 \%$ compared to 2010 .

The balance surplus of raspberries was on average of 74.62 .14 thousand tons in the analyzed period. Available natural resources and balance analysis shows that Serbia, with an adequate economic policy, can be a leading and permanent exporter of raspberries and its products. It is necessary to invest in the development of raspberry processing in a set of final products in order to increase profits. Namely, a wide range of various products is now produced in the world on the basis of raspberries.

In 2019 was achieved a higher yield and a further increase in raspberry exports. Longterm exports must be programmed by investing in plantations and processing. In addition to the export of fresh and frozen raspberries on the supply side in the world there are lyophilized raspberries, dried raspberries, candied raspberries and dried raspberries in various ways. We offer wines, brandies and raspberry vinegar, syrup, canned raspberries without seeds, jam, jam, dried ground seeds, jelly products and various pastes and creams, etc. Orientation should be on the processing of raspberries into a highly final assortment in order to achieve multiple profits in relation to the export of raw and frozen raspberries. Adequate program organization of production and processing and stimulating agricultural policy, given the quality, quantity and price 
competitiveness, should encourage the development of this production for permanent and profitable and anticipated export to the world market.

The balance analysis considered the production, consumption and foreign trade of raspberries in Serbia in the period 2010-2019. years. The balance analysis examined the realistically available production and consumption and showed the foreign trade turnover.

The research examined the influence of domestic production, imports and purchase prices on the supply of raspberries. Correlation analysis examined the impact of domestic production X1, imports X2 and purchase prices X3 on raspberry supply U. At the same time, correlation analysis examined the impact of domestic consumption X1, loss X2, exports X3, sales price X4 and income X5 on total raspberry demand.

Table 2. Influence of factors on the supply and marketing of raspberries

\begin{tabular}{|c|c|c|c|c|c|c|}
\hline Function & & Production & & Import & $\begin{array}{c}\text { redemption } \\
\text { price }\end{array}$ & \\
\hline Supply & $\mathbf{R}$ & $\mathbf{r 1}$ & $\mathbf{r} 2$ & $\mathbf{r 3}$ & $\mathbf{r} 4$ & \\
\hline $\begin{array}{c}\mathrm{y}=-23,56+1,342 \mathrm{X}_{1}- \\
4,898 \mathrm{X}_{2}-0,000035 \mathrm{X}_{3}\end{array}$ & 0,943 & 0,824 & & 0,02 & $\square 0,22$ & - \\
\hline Demand & & $\begin{array}{c}\text { Domestic } \\
\text { consumption }\end{array}$ & $\begin{array}{c}\text { Sales } \\
\text { prices }\end{array}$ & Income & export & $\begin{array}{c}\text { Final } \\
\text { stocks }\end{array}$ \\
\hline $\begin{array}{c}\mathrm{y}=39,19+ \\
0,55 \mathrm{X}_{1}-2,165 \mathrm{X}_{2^{-}} \\
0,304 \mathrm{X}_{3}+0,000063 \mathrm{X}_{4}- \\
0,25 \mathrm{X}_{5}\end{array}$ & 0,975 & 0,727 & 0,09 & $-0,613$ & 0,399 & 0,105 \\
\hline
\end{tabular}

Source: Author's calculation

The data from Table 2 show that the influence of prices, production and import on the change in the supply of raspberries is in the amount of $94.3 \%$.. When offering raspberries, there is a positive and a negative correlation of factors. Domestic production has a positive impact on supply. The increase in production will increase the supply by 1.34 thousand tons. Changes in imports and purchase prices negatively affect the supply of raspberries.

The next step is to determine the probability of a correlation. The value of $\mathrm{F}$ is 13.28 , which is significantly more than the required value, so it can be said that the created regression equation is valid and has an acceptable statistical significance in the supply prediction.

In order to obtain the desired results, a T-test was used to examine the influence of all coefficients on the supply of raspberries. The obtained results were compared with the critical value $\mathrm{t}(\alpha=0.05)$ and all were statistically significant and important for the purpose of formulating the regression equation on the supply side.

The analysis of the correlation of domestic production and supply of raspberries gave the value of 0.92 , which shows that there is a very high correlation. The value of the correlation between the import and supply of raspberries is 0.02 , which shows that there is a minimal correlation. 
After defining the equation on the supply side, an identical analysis was performed on the demand side. The data from Table 2 shows that the impact of consumption, loss, export and prices on the change in demand for raspberries is $97.5 \%$. When looking for raspberries, there is both a positive and a negative correlation of factors. Consumption has, for example, a positive effect, while loss and exports have a very negative impact on the demand for raspberries.

The next step is to determine the probability of a correlation. The value of F is 11.63 , which is significantly more than the required value, so it can be said that the created regression equation is valid and has an acceptable statistical significance in predicting the demand for raspberries.

In order to obtain the desired results, a T-test was used to examine the influence of all coefficients on the supply of raspberries. The obtained results were compared with the critical value $\mathrm{t}(\alpha=0.05)$ and all were statistically significant and important for the purpose of formulating the regression equation on the demand side.

Analyzed correlation between domestic consumption and total demand for raspberries the gave coefficient of 0.55 which shows the average correlation dependence. Value of the correlation between export, sale price, income and total demand shows the minimal negative correlation between the examined phenomena.

\section{Conclusion}

Supply and demand are two basic principles and represent the driving forces of the functioning of market economies. They determine the quantity of products that are produced and the price at which they are sold. It was confirmed that there is a direct positive correlation between price and supply on the market. In the study of market laws, the central place is occupied by the analysis of market demand. The market in Serbia has the characteristics of a perfectly competitive market on the supply side and the characteristics of ologopol on the demand side. There is a disorganization of purchases, producers and processors on the market. Agriculture with the food industry has a special economic, socio-economic and foreign trade significance. In the process of competing participants in the domestic and foreign markets, competitors strive to increase profits, market share.

Raspberry production in the analyzed period increased due to increased yields, although in most years it is maintained at a constant level. Serbia has exceptional comparative advantages in raspberry production. They are not fully valorized, but that is not the only and main problem. What is noticed is sometimes inadequate support of the state, which with its measures must accelerate and encourage producers not only to increase the yield on already planted plots, but also to expand them. That idea, as well as its realization, would be beneficial not only to the producers, but also to the entire economy. The benefits would also be reflected in the development of rural areas, because the mass production would raise the issue of infrastructure, which is currently at a very low level. 
This paper analyzes the supply and demand for raspberries, ie the impact of its factors on the production process. It was found that most factors had a statistically significant impact with some that were positive and others that were negative. What can be underlined as a general conclusion is that macroeconomic indicators are very important factors in the success of production, but also the demand for raspberries. Prosperity in the economic sense, which has been noticeable in recent years, can only be a springboard that will remind economic policy makers that the comparative advantages that a country has must be used in a way that will give everyone only benefits that can be seen from different angles. The obtained research results enabled the creation of regression equations on both supply and demand sides. As these factors are of a macroeconomic nature, it is clear how important the active role of the state is as well as its promptness in adopting appropriate measures. The formulated equations on the supply and demand side can be used to predict the examined categories and to eliminate the risk of uncertainty as much as possible. In a business environment full of risk but also competition, this is a very important thing, perhaps another advantage that should be used. Considering that factors are defined on the supply and demand side, but also their importance for supply and demand, it is possible to concentrate on some of these factors and influence the consequences on supply and demand for raspberries by influencing them.

Also, it is very important to look at the competition in the global market and see the trends as well as the types of products based on raspberries. Exporting unprocessed raspberries is lucrative, but it is even more profitable to export raspberry-based products. We have to keep up with this trend, because the market is ruthless and the acquired positions are being lost very quickly. It is important to create such a relationship between buyers and sellers that will be characterized by mutual trust. Such a relationship is very difficult to lose, but difficult to achieve. Certainly, Serbia has all the necessary potentials to be a leader on the world raspberry market, regardless of the important place it occupies on a global scale. We should not forget that raspberry is the most important Serbian brand.

\section{Conflict of interests}

The authors declare no conflict of interest.

\section{References}

1. Apáti, F. (2014). Farm economic evaluation of raspberry production. International Journal of Horticultural Science, 20(3-4), 53-56. https://doi.org/10.31421/ IJHS/20/3-4/1135

2. Babić, M. (2004). Makroekonomija, Zagreb, Mate.

3. Babović, J. (1997), Svetsko tržište i dugoročni razvoj poljoprivrede, sela i prehrambene industrije, Agroekonomika, Novi Sad.

4. Babović, J. (2009) Menadžment farme u održivoj proizvodnji, Fakultet za ekonomiju i inženjerski menadžment, Novi Sad. 
5. Bodiroga, R., \& Sredojević, Z. (2017). Economic Validity of Organic Raspberry Production as a Challenge for Producers in Bosnia and Herzegovina. Economic Insights - Trends and Challenges, 6(1), 5-15.

6. Bojkovska, K., Jankulovski, N., Mihajlovski, G., \& Momirceski, J. (2020). Analysis of market opportunities for raspberry production in the Republic of North Macedonia. International Journal of Research -GRANTHAALAYAH, 8(12), 149154. https://doi.org/10.29121/granthaalayah.v8.i12.2020.2698

7. Božidarević, D. (2002). Marketing poljoprivrednih i prehrambenih proizvoda. Poljoprivredni fakultet, Novi Sad.

8. Đorđević, D. (2006). Mikroekonomija - savremeni pristup, Novi Sad, Privredna akademija, Spoljnotrgovinski fakultet.

9. Đorđević, S., \& Mitić, N. (2020). Alternative accounting procedures, creative accounting and false financial reporting. Oditor - časopis za menadžment, finansije i pravo, 6(2), 21-37. https://doi.org/10.5937/Oditor2002021D

10. Đorović, M., Tomin, A. (2010) Trište i promet poljoprivrednih proizvoda, treće izdanje, Poljoprivredni fakultet, Beograd.

11. Farnsworth, D, Hamby, K., Bolda, M., Goodhue, R., Williams, J., \& Zalom, F. (2017). Economic analysis of revenue losses and control costs associated with the spotted wing drosophila, Drosophila suzukii (Matsumura), in the California raspberry industry. Pest management science, 73(6), 54-78. https://doi.org/10.1002/ps.4497

12. Filipović, J., \& Šapić, S. (2020). The impact of consumers' traveling and media activities on consumer behaviour towards purchasing global brands. Hotel and Tourism Management, 8(1), 25-35. https://doi.org/10.5937/menhottur2001025F

13. Hanić, H. (1990). Teorija i ekonometrijski modeli potrošačke tražnje. Ekonomski fakultet, Beograd.

14. Hanić, H. (2005), Istraživanje tržišta i marketing informacioni sistem. Ekonomski fakultet, Beograd

15. Jokić, M. (2020). The importance of considering internal audit as a decision-making by top-management of an agricultural company. Oditor - časopis za menadžment, finansije i pravo, 6(2), 123-136. https://doi.org/10.5937/Oditor2003123J

16. Jurin, S., \& Šohinger, J. (1990). Teorija tržišta i cena. Globus.Zagreb,

17. Kiš, T. (2005). Kvantitativni metodi u ekonomiji, Subotica, Ekonomski fakultet.

18. Kotler, F. (2003) Kako kreirati, upravljati i dominirati tržištem, Adižes, Novi Sad.

19. Mankiw, G. \& Taylor, P. (2008). Ekonomija. Data Status, Beograd.

20. Mankiw, G. (2008). Principi ekonomije, Beograd, Ekonomski fakultet.

21. Milić, D., Sredojević, Z., \& Bulatović-Lukač, M. (2017). Sustainability organizational-economic model of value chain organic raspberry. Journal on Processing and Energy in Agriculture, 21(3), 163-167. https://doi.org/10.5937/ JPEA1703163M 
22. Paraušić, V., \& Simeunović, I. (2016). Market analysis of serbia's raspberry sector and cluster development initiatives. Economics of Agriculture, 63(4), 1417-1431. https://doi.org/10.5937/ekoPolj1604417P

23. Pejanović, R. (2007). Ekonomija II, Uvod u mikroekonomiju. Poljoprivredni fakultet, Novi Sad.

24. Porter, M. (1990). The Competitive Advantage of Nations. The Free Press A division of Macmillan, Inc., New York.

25. Radosavljević, K. (2016). Enhancing agri-competitiveness: A cost-benefit analysis of raspberry production on a family farm. Ekonomika preduzeća, 64(7-8), 492-498. https://doi.org/10.5937/ekopre1608492R

26. Republički zavod za statistiku (RZS), Retrieved from www.stat.gov.rs (October 15, 2021).

27. Samuelson, P. (2007). Classical and Neoclassical harmonies and dissonances. The European journal of the history of economic thought, 14(2), 243-271. https://doi. org/10.1080/09672560701327950

28. Stanković, V., Mrdak, G., \& Miljković, M. (2020). Economic-legal analysis of international investments. Oditor - časopis za menadžment, finansije i pravo, 6(3), 89-122. https://doi.org/10.5937/Oditor2003089S

29. Šapić, S., Furtula, S., \& Durkalić, D. (2018). Prestige and national identity as predictors of food products purchase. Ekonomika Poljoprivrede, 65(2), 643-657. https://doi.org/10.5937/ekopolj1802643s

30. Temelkov, Z. (2020). Overview of price discrepancies among hotels positioned in the same category. Hotel and Tourism Management, 8(2), 11-23. https://doi. org/10.5937/menhottur2002011T

31. Wróblewska, W., Pawlak, J., \& Paszko, D. (2019). Economic aspects in the raspberry production on the example of farms from Poland, Serbia and Ukraine. Journal of Horticultural Research, 27(2), 71-80. https://doi.org/10.2478/johr-2019-0019 